\title{
Bio-surveillance of environmental pollutants in the population of Kinshasa, Democratic Republic of Congo (DRC): a small pilot study
}

Trésor Bayebila Menanzambi ${ }^{1 *}$ (D) Patrice Dufour ${ }^{2,3}$, Catherine Pirard ${ }^{2,3}$, Jean Nsangu ${ }^{1}$, Jean-Pierre Mufusama ${ }^{1}$, Jérémie Mbinze Kindenge ${ }^{1}$, Roland Marini Djang'eing' ${ }^{3}$ and Corinne Charlier ${ }^{2,3}$

\begin{abstract}
Background: Environmental pollutants are known to be ubiquitous and may present toxic effects (endocrinedisruption properties, carcinogenicity ...) and represent a real threat to human health. The aim of the present pilot study was to assess the content of environmental pollutants (inorganic, persistent, and non-persistent pollutants) in biological samples (urine, serum, and whole blood), collected from volunteers in Kinshasa, capital of Democratic Republic of Congo, in order to identify pollutants of interest and to design a protocol for a larger scale study.

Methods: From randomly selected 15 volunteers living in Kinshasa, aged from 25 to 66 years, (mean age $=43.4$ years), including 10 men and 5 women, urine, whole blood, and serum samples were used in this study to estimate the contents in these environmental pollutants, using inductively coupled plasma mass spectrometry, gas chromatography coupled to mass spectrometry, and liquid chromatography coupled to mass spectrometry.

Results: When compared to data nationally and internationally available, the preliminary outcomes of this study indicated a very high level of exposure to environmental pollutants in the population of Kinshasa, especially for heavy metals, parabens and triclosan. To a lesser extent, contamination measured for glyphosate, phthalates, organochlorine pesticides, pyrethroids and dialkylphosphate pesticides was also significant. In contrast, the investigated population of Kinshasa was found to be weakly exposed to other persistent organic pollutants like polychlorinated biphenyls, brominated flame retardants, phenolic organohalogens, and perfluoroalkyl substances.

Conclusion: Although the biologic fluids were collected from a limited number of volunteers $(n=15)$, the results of the present report clearly indicate that the population of Kinshasa is not spared by the investigated environmental pollutants. Moreover, this study gives us important information to design a larger scale study protocol.
\end{abstract}

Keywords: Bio-surveillance, Small pilot study, Environmental pollutants, Urine, Serum, Whole blood, Kinshasa

* Correspondence: baytresor_pharma@yahoo.fr

'Faculty of Pharmaceutical Sciences, University of Kinshasa, Kinshasa, Democratic Republic of the Congo

Full list of author information is available at the end of the article

C The Author(s). 2021 Open Access This article is licensed under a Creative Commons Attribution 4.0 International License, which permits use, sharing, adaptation, distribution and reproduction in any medium or format, as long as you give appropriate credit to the original author(s) and the source, provide a link to the Creative Commons licence, and indicate if changes were made. The images or other third party material in this article are included in the article's Creative Commons licence, unless indicated otherwise in a credit line to the material. If material is not included in the article's Creative Commons licence and your intended use is not permitted by statutory regulation or exceeds the permitted use, you will need to obtain permission directly from the copyright holder. To view a copy of this licence, visit http://creativecommons.org/licenses/by/4.0/. The Creative Commons Public Domain Dedication waiver (http://creativecommons.org/publicdomain/zero/1.0/) applies to the data made available in this article, unless otherwise stated in a credit line to the data. 


\section{Background}

Environmental protection is a key to the sustainable development. For decades, the environment has indeed been threatened by different human activities due to industrialization, including progress in agriculture, growing use of plastic materials, fire management products, pharmaceuticals, and cosmetics [1]. Since decades, the correlation between the increase in chemical production and that of the chronic disease prevalence has suggested that some chemicals may be responsible of endocrine disruptions, carcinogenicity, or other toxic effects [2-4]. As these compounds are ubiquitous and can operate at low concentrations, their release in the environment poses a potential threat to human health $[5,6]$. The actual systemic exposure of an individual to environmental pollutants can be evaluated by the quantification of these compounds or their metabolites in biological fluids [7].

Although being a controversy topic, many biosurveillance studies have reported harmful effects of environmental pollutants in humans. Among compounds presumed to have health-threatening properties, on one hand, persistent organic pollutants (POPs) are organic compounds with remarkable resistance to degradation into environment and among which there are organochlorine pesticides (OCP), polychlorinated biphenyls (PCB), brominated flame retardants (BFR), phenolic organo-halogens (POH), and perfluoroalkyl substances (PFAS). Among the health concerns associated to these compounds we could mention diseases affecting the central nervous system, metabolic diseases, and birth weight alteration [8]. On the other hand, inorganic pollutants (IP), especially arsenic, cadmium, lead, cobalt, tin, etc., are mineral compounds and many of them are likely used in several industrial activities. Some of them are alleged of being neurotoxic and of having damaging effects to noble organs like kidney, liver, heart, etc. [9]. Furthermore, non-persistent organic pollutants (nPOPs) like pyrethroids, alkyl-phosphates, bisphenols, triclosan, phthalates, parabens, glyphosate, and benzophenone, are organic compounds with fast degradation into environment but industrially produced in large amounts and are suspected to be responsible of several dysfunctions of the hormonal systems (reproductive or thyroid system), central nervous system, and in the occurrence of metabolic and chronic diseases [10].

With an area of $9965 \mathrm{~km}^{2}$ and an estimated population of 14.3 Million of inhabitants in 2020, Kinshasa is the capital, the most populated and the biggest city of the Democratic Republic of the Congo (DRC). Besides an important demographic increase, there is also an increase in morbidity and mortality rates due to chronic and metabolic diseases [11-13]. Moreover, Tuakuila J. et al. 2015 [14] reported a lack of data on biosurveillance of environmental pollutants in the population of Sub-Saharan African countries in general and particularly in DRC. This lack of data poses a big limitation in the surveillance of exponentially growing pathologies and highlights that very few resources are dedicated to the biomonitoring of environmental pollutants in Sub-Saharan Africans populations. Consequently, before performing large scale investigations, pilot studies are required to identify compounds that contaminate individuals at high levels. Identifying such pollutants would help to coherently attribute limited resources to the study of compounds potentially associated with higher health risks which subsequently could prompt local stakeholders to implement targeted and effective environmental policies.

In the present study, we assessed the content of environmental pollutants (inorganic, persistent, and nonpersistent pollutants) in biological samples (urine, serum, and whole blood), collected from 15 volunteers aging from 25 to 66 years (mean age $=43.4$ years), belonging to various business sectors, and living in Kinshasa. The aim of the investigation was to estimate roughly the exposure level of the population of Kinshasa to environmental pollutants and to identify chemicals that are present at high levels. This information will help us to write a study protocol for a future largescale study targeting compounds associated with potential high health impact on Kinshasa residents. To the best of our knowledge, this is the first study reporting on biosurveillance data of organic persistent and nonpersistent pollutants in the population of Kinshasa as well as in that of DRC.

\section{Methods}

\section{Sample collection}

Biological fluids were collected from 15 volunteers recruited in the population of Kinshasa with ages ranging from 25 to 66 years, the mean and the median age were 43.4 and 47.0 years respectively ( $\mathrm{SD}=14.3$ years), including 10 men and 5 women. For this small pilot biosurveillance study, with the aim to conduct the first exploration of pollutant contamination in the general population of Kinshasa and covering various exposition profiles, volunteers were selected among business sectors, including market gardeners, pesticide vendors, plastic manufacturers, aluminium utensil makers, mechanics, traders, students, lawyers, painters, drivers, teachers, polices, students, fitters, and sanitation technicians. In each sector, a volunteer was randomly chosen throughout the city. Prior to be enrolled, presumed volunteers belonging to various business sectors were directly informed about the study merits by the principal investigator in their workplace. One individual per sector was randomly selected among people who agree to participate to the study. This volunteer was invited to fulfil 
the consent form and was submitted to a questionnaire to record his/her age, business activity, commonly handled products, and duration of exposure. All fifteen volunteers filled out the questionnaire with the help of the principal investigator. Volunteers had to be over 18 years old, have worked full time for at least 1 year in the same workplace and individuals who were out of the city for at least 6 months for the last decade were excluded from the recruitment.

Early in the morning, after breakfast, each volunteer was requested to give about $10 \mathrm{~mL}$ of whole blood, kept in a plastic tube (without gel but with heparin), $10 \mathrm{~mL}$ of whole blood to prepare the serum, kept in a plastic tube (without gel and without heparin), and $50 \mathrm{~mL}$ of urine, kept in a polypropylene vial, all together 45 samples for analysis. These samples were collected between March and April 2019 and placed immediately in a dry ice enclosure, while ensuring that tubes with whole blood were not in direct contact with the ice, to avoid the risk of haemolysis and facilitating their transport, for proper storage, to the Clinical Biology Laboratory of the Faculty of Pharmaceutical Sciences at the University of Kinshasa. Tubes with whole blood for the preparation of the serum samples were centrifuged for $5 \mathrm{~min}$ at $3000 \mathrm{rpm}$ and kept, together with urine samples, in a freezer at $20^{\circ} \mathrm{C}$, while tubes of heparinized whole blood were stored in a fridge at $4{ }^{\circ} \mathrm{C}$. Toxicological analyses were carried out in the Laboratory of Clinical, Forensic and Environmental Toxicology, at the University of Liege, in Belgium. For a proper transport to Belgium, all samples were stored in a hermetically sealed enclosure with dry ice, while ensuring that the whole blood tubes were not in direct contact with the ice. The current study was approved by the national health ethics committee in the Congo under the series number of $159 / \mathrm{CNES} / \mathrm{BN} /$ PMMF/2020.

\section{Analytical procedures Analysis of metals and metalloids in urine}

The inorganic compounds (namely, $\mathrm{As}, \mathrm{Bi}, \mathrm{Cd}, \mathrm{Co}, \mathrm{Cr}$, $\mathrm{Cu}, \mathrm{Mn}, \mathrm{Mo}, \mathrm{Ni}, \mathrm{Sb}, \mathrm{Se}, \mathrm{Sn}, \mathrm{Tl}, \mathrm{V}$ and $\mathrm{Zn}$ ) were analysed using ICP-MS. Briefly, internal standard (containing Rh, Sc and Ge) was added, at the same time, to the sample, to the quality control sample, and to the standard calibration sample. This mixture was then diluted with an aqueous solution of nitric acid $0.5 \%$ before being injected into ICP-MS. For detailed analytical methodology, see supplementary information.

\section{Analysis of glyphosate in urine}

Urinary content in glyphosate was investigated following the procedure extensively described in the supplementary information. Briefly, urinary glyphosate in sample, quality control sample, and standard calibration sample was derivatized with fluorenylmethoxycarbonyl chloride (FMOC). A first liquid-liquid extraction was then performed to eliminate residual FMOC and nonpolar compounds. A second liquid-liquid extraction was performed after acidification to extract the analyte. After evaporation and reconstitution in vial, the sample was analysed by LC-MS/MS.

\section{Analysis of pyrethroids and organophosphate chlorpyrifos metabolites in urine}

Five pyrethroids metabolites (namely, cis- and trans-3(2,2-dichlorovinyl)-2.2-dimethylcyclopropane carboxylic acid (c- and t-DCCA), 3-phenoxybenzoic acid (3-PBA), 4-fluoro-3-phenoxybenzoic acid (4F-3-PBA) and 3-(2,2dibromovinyl)-2.2-dimethylcyclopropane carboxylic acid (DBCA) and one chlorpyrifos metabolite (namely 3,5,6trichloro-2-pyridinol (TCPY)) were analyzed according to the methodology detailed in Pirard et al. 2020 [15]. Briefly, urinary sample, quality control sample, and standard calibration sample were extracted with diethyl ether. The organic layer was evaporated to dryness and the residue was derivatized with N-tertbutyldimethylsilyl-N-methyltrifluoroacetamide

(MTBSTFA). The derivatized extract was then analysed by GC-MS/MS.

\section{Analysis of alkylphosphates in urine}

Five dialkylphosphates (DAPs) (nonspecific metabolites of organophosphate pesticides) (namely dimethylthiophosphate (DMTP), dimethyldithiophosphate (DMDTP), diethylphosphate (DEP), diethylthiophosphate (DETP) and diethyldithiophosphate (DEDTP)) were quantified in urine samples according to the methodology described in Pirard et al., 2020 [15]. In summary, urine sample, quality control sample, and standard calibration sample were extracted on solid phase extraction (SPE) cartridge. The eluate was evaporated to dryness and then derivatized with chloroiodopropane. The derivatized extract was then analysed by GC-MS/MS.

\section{Analysis of phthalate metabolites, parabens, and benzophenone-3 in urine}

The urinary concentrations of 7 phthalate metabolites (namely, monoethyl phthalate (MEP), mono-iso-butyl phthalate (MiBP), mono-n-butyl phthalate (MnBP), monobenzyl phthalate (MBzP), mono-2-ethylhexyl phthalate (MEHP), mono-2-ethyl-5-hydroxyhexyl phthalate (5-OH-MEHP) and mono-2-ethyl-5-oxohexyl phthalate (5-oxo-MEHP)), 4 parabens (namely, methylparaben (MeP), ethylparaben (EP), n-propylparaben $(\mathrm{PrP})$ and n-butylparaben (BP)) and benzophenone-3 were determined according to the methodology developed by Dewalque et al. 2014 [16]. Briefly, urine sample, quality control sample, and standard calibration sample 
were submitted to an enzymatic hydrolysis, then an extraction was performed using SPE cartridge and finally the extract was analysed on a LC-MS/MS apparatus.

\section{Analysis of triclosan and bisphenols in urine}

The levels of triclosan and 7 bisphenols (BP) (namely, BPA, BPAF, BPF, BPZ, BPAP, BPP and BPS) in urine samples were measured by using the methodology detailed in the supplementary materials. In summary, the sample, quality control sample, and standard calibration sample were submitted to an enzymatic hydrolysis followed by an extraction on a SPE cartridge. This first extraction was followed by a liquid-liquid extraction and then by a derivatization. The derivatized extract was then analysed by a GC-MS/MS [17].

\section{Analysis of lead in whole blood}

Lead was quantified in whole blood. Samples, quality control samples, and standard calibration samples were mixed with internal standard and diluted with a mixture of nitric acid (0.5\%), n-butanol (0.2\%) and triton (0.1\%) in water. The lead content was determined by using an ICP-MS. The procedure has been detailed in supplementary information.

\section{Analysis of polychlorobiphényls (PCBs) and organochlorine pesticides in serum}

Fifteen organochlorine pesticides or metabolites, (namely alpha-, beta-and gamma-HCH $(\alpha-, \beta-$ and $\gamma-\mathrm{HCH})$, hexachlorobenzene (HCB), aldrin, dieldrin, endrin, trans-chlordane, oxychlordane, trans-heptachlor epoxide, cis- and trans-nonachlor, 2,4'- and 4,4'-dichlorodiphenyl-dichloroethylene (DDE), beta-endosulfan) and 3 PCBs $(-138,-153$, and -180$)$ were quantified in serum. The analytical procedure was extensively detailed in Pirard et al. 2018 [1]. Briefly, sample, quality control sample, and standard calibration sample were denaturized with acetonitrile and a saturated potassium carbonate solution. The mixture was then extracted twice with hexane-acetone mixture $(9 / 1, \mathrm{v} / \mathrm{v})$. The organic phase was cleaned on a SPE cartridge and then evaporated and reconstituted in nonane. The extract was analysed on a GC-MS/MS apparatus.

\section{Analysis of BFRs in serum}

The methodology to quantify 8 polybrominated diphenylethers (PBDEs) (namely, BDE-28, - 47, - 99, - 100, 153, - 154, -183 and - 209) has been described in Pirard and Charlier, 2018 [18]. In summary, serum sample, quality control sample, and standard calibration sample were denaturized with a glacial acetic acid/water mixture $(3 / 7, v / v)$ and then extracted twice with a mixture of hexane and acetone $(95 / 5, \mathrm{v} / \mathrm{v})$. The organic phase was then cleaned on a PHREE cartridge, then evaporated and transferred into nonane. The quantification was performed using a GC-MS/MS.

\section{Analysis of perfluorinated alkyl subtances (PFAS) in serum} The quantification of the serum content in 7 PFASs (namely, perfluoro-octane sulfonic (PFOS), perfluoroctanoic acid (PFOA), perfluorohexane sulfonate (PFHxS), perfluorononanoic acid (PFNA), perfluorodecanoic acid (PFDA), perfluoroheptanoic acid (PFHpA) and perfluoroundecanoic acid (PFUdA)) was performed according to the methodology described in Dufour et al. 2018 [8]. Briefly, serum sample, quality control sample, and standard calibration sample were denaturized with formic acid/water mixture $(1 / 1, v / v)$. Then the sample was extracted on a weak anionic exchange SPE cartridge, the eluate was evaporated to dryness and then reconstituted in $80 \mu \mathrm{L}$ of a mixture of mobile phases. The extract was then analysed using a LC-MS/MS apparatus.

\section{Analysis of phenolic organohalogens ( $\mathrm{POHs}$ ) in serum}

POHs (namely, pentachlorophenol (PCP), tetrabromobisphenol A (TBBPA), 2,4,6-tribromophenol (2,4,6-TBP), 2,3,6-tribromophenol (2,3,6-TBP), 2,4,5-tribromophenol (2,4,5-TBP), 2,3,4,6-tetrabromophenol (2,3,4,6-TeBP), 6hydroxy-polybromodiphenylether 47 (6-OH-BDE 47), 5hydroxy-polybromodiphenylether 47 (5-OH-BDE 47), $5^{\prime}$-hydroxy-polybromodiphenylether $99 \quad\left(5^{\prime}-\mathrm{OH}-\mathrm{BDE}\right.$ 99), 4-hydroxy-polychlorinated biphenyl 107 (4-OH-CB 107), 3-hydroxy-polychlorinated biphenyl 138 (4-OH-CB 138), 4-hydroxy-polychlorinated biphenyl 146 (4-OH-CB 146), 3-hydroxy-polychlorinated biphenyl 153 (3-OH-CB 153), 4-hydroxy-polychlorinated biphenyl 172 (4-OH-CB 172), 3-hydroxy-polychlorinated biphenyl 180 (3-OH-CB 180) and 4-hydroxy-polychlorinated biphenyl 187 (4$\mathrm{OH}-\mathrm{CB}$ 187)) were analysed according to the method described in Dufour et al. 2016 [19]. In summary, the serum sample, quality control sample, and standard calibration sample were denaturized with a mixture of water/formic acid/2-propanol (50/40/10, v/v) and then extracted on a strong anionic exchange SPE cartridge. The eluate is then extracted with hexane; hexane phase was evaporated to dryness and then derivatized with trimethylsilyldiazomethane. The derivatized extract was then analysed using a GC-MS/MS.

\section{Analysis of creatinine in urine samples}

Adjustment to creatinine was used to normalize pollutant contents in urine samples. In this study, urinary creatinine was evaluated on an ARCHITECT $\mathrm{Ci} 4100$ automate from ABBOTT (Illinois, USA), using an immunoassay. 


\section{Quality assurance and statistical analysis}

To ensure the results quality, all analyses were covered by internal or external quality control sample and for each analysis, a specific internal standard was used as a recovery indicator and a correction factor. A specific calibration curve was applied for each analysis. All statistical analyses were performed using $\mathrm{R}$ programming software (version 3.6.3., CRAN) and Microsoft Excel 2013 (Microsoft, Redmond, WA). For analyses with results lower than the limit of quantification (LOQ), a correction was made by multiplying the LOQ by the detection frequency (DF), in order to valorise the investigation outcomes.

\section{Comparison with data reported in the literature}

In order to identify chemicals for which high concentration are measured in Kinshasan population, we compared our results with those reported in other studies performed on general populations originated from other countries around the world. First, we performed systematic research in Pubmed to identify the studies reporting pollutant contamination levels in Sub-Saharian Africans populations (we also included RDC). Secondly, because biomonitoring investigations are relatively numerous in Belgium, because contamination measured in Belgian population can be considered as roughly representative of the situation in Western Europe and because the Laboratory of Toxicology of the University Hospital of Liege is particularly involved in the biomonitoring of the Belgian population, for each family of pollutants we compared our data with those reported in studies performed on general Belgian population. Finally, we searched in Pubmed, articles reporting pollutant contamination measured in general populations around the world, the aim was not to perform a systematic review of the literature so we reported only few examples for each compounds family and we were attentive to exclude studies assessing populations with identified significant source of contamination.

\section{Results}

Tables 1 and 2 gather results for the most significant and most representative compounds for each family of pollutants. The results for the entire set of chemicals are reported in supplementary information.

Table 1 shows the qualification limits of the used methods for each pollutant as well as their detection frequencies, respectively in $\mathrm{pg} / \mathrm{mL}$ and in percentage (\%).

Table 2 presents arithmetic and geometric means, medians, minimum and maximum contents in urine, whole blood, and serum samples of some pollutants or their corresponding biomarkers. Being robust at extreme values, the median concentrations were considered as reference points.
Results obtained from urine samples analyses were presented in $\mu \mathrm{g} / \mathrm{L}$, and in $\mu \mathrm{g} / \mathrm{g}$ of creatinine in parenthesis. Many bio-surveillance studies have suggested that only considering the expression of concentration adjusted by creatinine could lead to a bias when comparing different populations, pollutants contents in urine samples in comparative studies were only reported in $\mu \mathrm{g} / \mathrm{L}$ $[20,21]$. Analyses of serum and whole blood samples are expressed in $\mu \mathrm{g} / \mathrm{L}$ or in $\mathrm{pg} / \mathrm{mL}$ (different unities were used to facilitate study comparison).

All comparison results at both national and international scale are presented in Tables 3 and 4, and Figs. 1 and 2.

\section{Discussion}

\section{Metals in urine}

Except for Mn (detected at 20\%), Sn and Sb (detected each at 47\%), and Cd (detected at 93\%), all other inorganic and metalloid compounds, investigated in urine were detected in all samples. Detected in most of the samples and with a median concentration of $70.91 \mu \mathrm{g} / \mathrm{L}$, the population of Kinshasa is clearly more exposed to arsenic than populations in two other studies conducted in mining and industrial areas in Spain (Huelva) and in the DRC (Lubumbashi) (Table 3). Collected from 261 students, the first study reported a median content of $1.17 \mu \mathrm{g} / \mathrm{L}$, while, the second study, based on 39 pregnant women (control population), stated a median concentration 3 times lower than here reported, probably due to an important food intake in Kinshasa, arising the necessity to figure out the exposure source and to identify the vulnerable population [22, 23]. With a median concentration of $0.61 \mu \mathrm{g} / \mathrm{L}$, the cadmium exposure here reported seemed to be similar to those measured in the above-mentioned study (control population) from Lubumbashi [23], but two fold higher than the one reported in Spain, with a median content of $0.29 \mu \mathrm{g} / \mathrm{L}$ [22], but also than that stated in two Belgian studies, the first involving a population of 52 men of Ath with a geometric mean of $0.21 \mu \mathrm{g} / \mathrm{L}$ [24], and the second exploring 125 Belgian mothers reporting a median value of $0.22 \mu \mathrm{g} / \mathrm{L}$ [7] (Table 3).

\section{Glyphosate}

Used in agriculture for crop protection, glyphosate, a widely used organophosphorus herbicide worldwide, is currently classified in Category 2A "probably carcinogenic to humans" by the International Agency for Research on Cancer (IARC) [25].

The glyphosate median outcome $(0.23 \mu \mathrm{g} / \mathrm{L})$ of the current study was far lower than that stated on 50 Irish adults with a median concentration of $0.87 \mu \mathrm{g} / \mathrm{L}$ [25]. But the study from Conrad A. et al. 2017 [26] on 40 German adults reported a lower median content 
Table $1 \mathrm{LOQ}$ of methods (pg/mL) and DF (\%) of environmental pollutants in Kinshasa

\begin{tabular}{|c|c|c|c|c|c|c|c|}
\hline matrix & pollutant & LOQ & DF & matrix & pollutant & LOQ & DF \\
\hline Inorganics Pollutants & & & & & & & \\
\hline \multirow[t]{15}{*}{ Urine } & Vanadium & 180 & 73 & Urine & Parabens & & \\
\hline & Chrome & 230 & 100 & & $\mathrm{MeP}$ & 790 & 100 \\
\hline & Manganese & 890 & 20 & & EP & 300 & 67 \\
\hline & Cobalt & 130 & 100 & & PrP & 360 & 100 \\
\hline & Nickel & 1630 & 100 & & Phthalates & & \\
\hline & Cadmium & 120 & 93 & & MEP & 940 & 100 \\
\hline & Tin & 730 & 47 & & MEHP & 620 & 100 \\
\hline & Antimony & 140 & 47 & & $\mathrm{MnBP}$ & 990 & 100 \\
\hline & Thalium & 90 & 100 & & MiBP & 1230 & 100 \\
\hline & Bismuth & 120 & 100 & & MBzP & 610 & 87 \\
\hline & Copper & 1600 & 100 & & Benzophenone & & \\
\hline & Zinc & 15,000 & 100 & & BP3 & 670 & 100 \\
\hline & Arsenic & 140 & 100 & & Pyrethroid pesti & & \\
\hline & Selenium & 7900 & 100 & & $c-D C C A$ & 150 & 87 \\
\hline & Molybdene & 5000 & 100 & & $\mathrm{t}-\mathrm{DCCA}$ & 150 & 93 \\
\hline \multirow[t]{2}{*}{ Blood } & Lead & 500 & 100 & & TCPY & 80 & 100 \\
\hline & & & & & DBCA & 300 & 87 \\
\hline \multirow[t]{22}{*}{ Serum } & Organochlorine pesticides & & & & FPBA & 110 & 7 \\
\hline & $4,4^{\prime}-\mathrm{DDE}$ & 400 & 87 & & 3-PBA & 90 & 100 \\
\hline & $\mathrm{HCB}$ & 80 & 7 & & Triclosan & & \\
\hline & $\beta-\mathrm{HCH}$ & 50 & 0 & & TCS & 200 & 100 \\
\hline & Polychlorinated biphenyls & & & & Bisphenols & & \\
\hline & PCB 153 & 70 & 60 & & BPF & 70 & 67 \\
\hline & PCB 138 & 150 & 7 & & BPA & 290 & 100 \\
\hline & PCB 180 & 50 & 53 & & $\mathrm{BPZ}$ & 60 & 0 \\
\hline & Perfluoroalkyl substances & & & & BPS & 90 & 80 \\
\hline & PFOA & 250 & 100 & & \multicolumn{3}{|c|}{ Organophosphate pesticide } \\
\hline & PFOS & 500 & 47 & & DEP & 500 & 53 \\
\hline & PFHxS & 150 & 60 & & DETP & 500 & 47 \\
\hline & PFNA & 100 & 60 & & Glyphosate & & \\
\hline & \multicolumn{2}{|l|}{ Brominated flame retardants } & & & Glyphosate & 80 & 93 \\
\hline & PBDE 47 & 3.7 & 27 & & & & \\
\hline & PBDE 153 & 4.2 & 27 & & & & \\
\hline & \multicolumn{3}{|l|}{ Phenolic organohalogens } & & & & \\
\hline & PCP & 44.6 & 14 & & & & \\
\hline & 2,4,6 TBP & 49.6 & 0 & & & & \\
\hline & 4-OH CB 146 & 2.2 & 29 & & & & \\
\hline & 4-OH CB 187 & 2 & 57 & & & & \\
\hline & 6-OH BDE 47 & 2.5 & 0 & & & & \\
\hline
\end{tabular}


Table 2 Mean, geometric mean, median and range concentrations in urine $[\mu \mathrm{g} / \mathrm{L}(\mu \mathrm{g} / \mathrm{g}$ creatinine)] and at both blood and serum in $\mu \mathrm{g} / \mathrm{L}$

\begin{tabular}{|c|c|c|c|c|c|c|}
\hline & Pollutant & Mean & Geometric mean & Median & Minimum & Maximum \\
\hline \multirow[t]{20}{*}{ Urinary } & Cobalt & $1.0(0.31)$ & $0.57(0.24)$ & $0.43(0.21)$ & $0.16(0.089)$ & $6.11(0.87)$ \\
\hline & Cadmium & $1.15(0.33)$ & $0.66(0.28)$ & $0.61(0.26)$ & ८OQ («LOQ) & $6.12(0.87)$ \\
\hline & Arsenic & 81.74 (32.33) & 69.73 (29.79) & 70.91 (30.86) & $32.12(11.97)$ & $215.32(57.28)$ \\
\hline & Glyphosate & $0.22(0.095)$ & $0.19(0.083)$ & $0.23(0.098)$ & $0.09(0.05)$ & $0.40(0.18)$ \\
\hline & MeP & 699.98 (335.48) & 216.12 (92.32) & 445.39 (121.96) & 15.06 (9.94) & 4467.5 (1386.5) \\
\hline & EP & 11.94 (2.96) & $0.73(0.31)$ & $0.47(0.25)$ & «OQ («LOQ) & 86.5 (26.83) \\
\hline & PrP & 290.62 (157.53) & $38.96(16.64)$ & 31.35 (5.35) & $0.97(0.65)$ & 2509.15 (778.75) \\
\hline & MEP & 309.94 (96.09) & 113.09 (48.31) & $108.56(41.96)$ & $13.96(9.45)$ & 2366.9 (734.6) \\
\hline & MEHP & 16.47 (6.26) & $8.53(3.64)$ & $9.03(3.25)$ & $0.97(0.84)$ & 62.45 (15.75) \\
\hline & $\mathrm{MnBP}$ & 229.67 (92.86) & $176.42(75.36)$ & $145.19(60.72)$ & 32.05 (31.79) & $638.11(292.3)$ \\
\hline & MiBP & 31.39 (13.42) & $25.26(10.79)$ & 26.52 (9.32) & $7.43(4.1)$ & 72.37 (27.97) \\
\hline & BP3 & $6.76(2.59)$ & $4.97(2.12)$ & $5.00(1.93)$ & $0.76(0.65)$ & $23.31(6.67)$ \\
\hline & $c-D C C A$ & $0.81(0.28)$ & $0.41(0.18)$ & $0.47(0.23)$ & «OQ («LOQ) & $3.9(0.69)$ \\
\hline & $\mathrm{t}-\mathrm{DCCA}$ & $1.34(0.47)$ & $0.72(0.31)$ & $0.59(0.31)$ & «OQ («LOQ) & $0.17(0.12)$ \\
\hline & TCPY & $37.68(13.52)$ & 9.19 (3.92) & $4.43(2.19)$ & $0.40(0.44)$ & $123.36(54.6)$ \\
\hline & 3-PBA & 16.88 (4.84) & $3.36(1.44)$ & $2.25(1.22)$ & $0.29(0.15)$ & $173.20(48.50)$ \\
\hline & TCS & $90.44(44.45)$ & $40.88(17.46)$ & $40.13(17.76)$ & $4.48(0.64)$ & $277.82(184.70)$ \\
\hline & $\mathrm{BPA}$ & $1.96(0.88)$ & $1.62(0.69)$ & $1.36(0.76)$ & $0.52(0.38)$ & $5.40(2.08)$ \\
\hline & DEP & $4.30(1.24)$ & $0.30(0.13)$ & $0.87(0.19)$ & «OQ («LOQ) & 32.70 (9.18) \\
\hline & DETP & $1.95(0.63)$ & $0.76(0.33)$ & $0.35(0.24)$ & «OQ («LOQ) & $9.23(2.34)$ \\
\hline Blood & Lead & 62.96 & 53.69 & 53.57 & 22.34 & 156.96 \\
\hline \multirow[t]{8}{*}{ Serum } & $4,4^{\prime} \mathrm{DDE}$ & 3.02 & 1.69 & 1.46 & $\ll \mathrm{LQ}$ & 9.20 \\
\hline & PCB 153 & 0.09 & 0.08 & 0.08 & ८OQ & 0.20 \\
\hline & PFOA & 0.49 & 0.47 & 0.48 & 0.25 & 0.85 \\
\hline & PFOS & 0.58 & $\ll \mathrm{LOQ}$ & 0.50 & $\ll \mathrm{QQ}$ & 1.54 \\
\hline & PCP & $\measuredangle \mathrm{LQQ}$ & $\measuredangle \mathrm{LQQ}$ & $\measuredangle \mathrm{LQQ}$ & ८OQ & $102.4^{a}$ \\
\hline & 4-OH CB187 & $7.48^{\mathrm{a}}$ & $<\mathrm{LQ}$ & $2.44^{\mathrm{a}}$ & $\ll \mathrm{LQ}$ & $20.4^{a}$ \\
\hline & PBDE47 & $<\mathrm{LOQ}$ & $\ll \mathrm{LOQ}$ & $\ll \mathrm{LOQ}$ & $\ll \mathrm{QQQ}$ & $15.06^{\mathrm{a}}$ \\
\hline & PBDE 153 & $\ll \mathrm{LOQ}$ & $\ll \mathrm{LOQ}$ & ¿LQ & ¿OQ & $13.45^{\mathrm{a}}$ \\
\hline
\end{tabular}

${ }^{a}$ concentration in $\mathrm{pg} / \mathrm{mL}$

LOQ Limit of Quantification

$(0.11 \mu \mathrm{g} / \mathrm{L})$ than that stated here (Table 3). This result shows a clear glyphosate exposure in the investigated population of Kinshasa, due to a probable usage of this powerful herbicide by farmers or its possible presence in the various imported food products.

\section{Lead}

Human exposure to lead ( $\mathrm{Pb})$ is caused by various industrial activities such as metallurgy, printing, ammunition, paintings, batteries of accumulators, etc. Atmospheric lead, which is largely responsible for lead body burden, is usually derived from gasoline products where it is used as an anti-detonator [14].
When compared to international studies conducted on 156 women in Beijing [27] and on 52 men in Belgium [24], with respective median content values of $17.6 \mu \mathrm{g} / \mathrm{L}$ and $31.7 \mu \mathrm{g} / \mathrm{L}$, the median concentration here presented was higher $(53.6 \mu \mathrm{g} / \mathrm{L})$ (Table 3). These differences could probably be explained by a more important lead exposure source in Kinshasa, reinforcing the need to search for exposure source and to identify the vulnerable population.

In a national level, the observed median content was higher to the one of the control population from the 39 women study in Lubumbashi [23], reporting a median concentration of $50.8 \mu \mathrm{g} / \mathrm{L}$, although the study of Tuakuila J. et al. 2013 [28] stated a higher median content of 
Table 3 Pollutants median values $(\mu \mathrm{g} / \mathrm{L})$ measured in urine, blood and serum from different worldwide populations

\begin{tabular}{|c|c|c|c|c|c|}
\hline Pollutant & matrix & Year of collection & Population & Median & Reference \\
\hline \multirow[t]{4}{*}{ Arsenic } & Urine & & & & \\
\hline & & 2012 & Huelva (Spain), school children, $N=261$ & 1.17 & [22] \\
\hline & & $2012-2013$ & Lubumbashi (DRC), pregnant women (control), $N=39$ & $23.60^{\mathrm{a}}$ & [23] \\
\hline & & 2019 & Kinshasa (DRC), population, $N=15$ & 70.90 & Current study \\
\hline \multirow[t]{4}{*}{ Cobalt } & Urine & & & & \\
\hline & & 2009 & Ath-Belgium, men population, $N=52$ & $0.16^{\mathrm{a}}$ & [24] \\
\hline & & $2012-2013$ & Lubumbashi (DRC), pregnant women (control), N = 39 & $6.97^{\mathrm{a}}$ & [23] \\
\hline & & 2019 & Kinshasa (DRC), population, $N=15$ & 0.43 & Current study \\
\hline \multirow[t]{6}{*}{ Cadmium } & Urine & & & & \\
\hline & & 2009 & Ath-Belgium, men population, $N=52$ & $0.21^{\mathrm{a}}$ & [24] \\
\hline & & $2011-2012$ & Belgium, mother, $N=125$ & 0.22 & [7] \\
\hline & & 2012 & Huelva (Spain), school children, $N=261$ & 0.29 & [22] \\
\hline & & $2012-2013$ & Lubumbashi (DRC), pregnant women (control), $N=39$ & $0.60^{a}$ & [23] \\
\hline & & 2019 & Kinshasa (DRC), population, $N=15$ & 0.61 & Current study \\
\hline \multirow[t]{6}{*}{ Lead } & Blood & & & & \\
\hline & & 2009 & Ath-Belgium, men population, $N=52$ & $31.70^{\mathrm{a}}$ & [24] \\
\hline & & 2011 & Kinshasa (DRC), children $1-5$ years, $N=100$ & 86.00 & [28] \\
\hline & & 2012-2013 & Lubumbashi (DRC), pregnant women (control), $N=39$ & $50.80^{a}$ & [23] \\
\hline & & 2015-2016 & Beijing, maternal blood, $N=156$ & 17.60 & [27] \\
\hline & & 2019 & Kinshasa (DRC), population, $N=15$ & 53.60 & Current study \\
\hline \multirow[t]{4}{*}{ Glyphosate } & Urine & & & & \\
\hline & & 2012 & German, adult population, $N=40$ & 0.11 & [26] \\
\hline & & 2017 & Irish, adult population, $N=50$ & 0.87 & [25] \\
\hline & & 2019 & Kinshasa (DRC), population, $N=15$ & 0.23 & Current study \\
\hline \multirow[t]{5}{*}{ BP3 } & Urine & & & & \\
\hline & & 2011 & Danish, mother, $N=145$ & 3.70 & [30] \\
\hline & & 2012 & Tunisia, women, $N=34$ & 1.73 & [32] \\
\hline & & 2013 & Belgium, adult population, $N=261$ & 1.30 & [20] \\
\hline & & 2019 & Kinshasa (DRC), population, $N=15$ & 5.00 & Current study \\
\hline \multirow[t]{6}{*}{$4,4^{\prime} D D E$} & Serum & & & & \\
\hline & & 2010-2011 & Bolivian, women agriculture, $N=24$ & 9.34 & [42] \\
\hline & & $2012-2013$ & South-Africa, pregnant women, $N=733$ & $1.75^{\mathrm{b}}$ & [46] \\
\hline & & 2013-2015 & Lebanon, population, $N=314$ & $0.13^{b}$ & [45] \\
\hline & & 2015 & Belgium, adult population (women), $N=124$ & 0.41 & [1] \\
\hline & & 2019 & Kinshasa (DRC), population, $N=15$ & 1.46 & Current study \\
\hline \multirow[t]{5}{*}{ PCB 153} & Serum & & & & \\
\hline & & $2005-2007$ & Anniston Community (USA), African-American, $N=353$ & $1.42^{b}$ & [47] \\
\hline & & 2013-2015 & Lebanon, population, $N=314$ & $0.12^{b}$ & [45] \\
\hline & & 2015 & Belgium, adult population, $N=251$ & 0.36 & [1] \\
\hline & & 2019 & Kinshasa (DRC), population, $N=15$ & 0.081 & Current study \\
\hline
\end{tabular}


Table 4 Pollutants median values $(\mu \mathrm{g} / \mathrm{L})$ measured in urine and serum from different worldwide populations

\begin{tabular}{|c|c|c|c|c|c|c|c|c|c|c|c|}
\hline \multirow[t]{2}{*}{$\begin{array}{l}\text { Year of } \\
\text { collection }\end{array}$} & \multirow[t]{2}{*}{ Population } & \multicolumn{3}{|c|}{ Parabens in urine } & \multicolumn{2}{|c|}{$\begin{array}{l}\text { Perfluoroalkyl } \\
\text { substances in } \\
\text { serum }\end{array}$} & \multicolumn{2}{|c|}{$\begin{array}{l}\text { Alkylphosphates } \\
\text { in urine }\end{array}$} & \multirow[t]{2}{*}{$\begin{array}{l}\text { BPA in } \\
\text { urine }\end{array}$} & \multirow[t]{2}{*}{$\begin{array}{l}\text { TCS in } \\
\text { urine }\end{array}$} & \multirow[t]{2}{*}{ Reference } \\
\hline & & MeP & EP & PrP & PFOS & PFOA & DEP & DETP & & & \\
\hline 2013 & Belgium,adult,population, $N=261$ & 16.1 & 1.7 & 1.2 & - & - & - & - & - & - & [20] \\
\hline 2011 & Danish, mother, $N=145$ & 14 & 0.89 & 1.7 & - & - & - & - & - & - & [30] \\
\hline $\begin{array}{l}2010- \\
2011\end{array}$ & Spain, Young men, $N=215$ & 17 & 1.8 & 0.7 & - & - & - & - & - & - & [33] \\
\hline 2012 & Tunisia, women, $N=34$ & 34.94 & 1.77 & 3.06 & - & - & - & - & - & - & [32] \\
\hline $\begin{array}{l}2015- \\
2018\end{array}$ & Belgium, population, $N=237$ & - & - & - & 3.61 & 1.6 & - & - & - & - & [48] \\
\hline $\begin{array}{l}2014- \\
2016\end{array}$ & $\begin{array}{l}\text { USA, adolescents exposed, } N= \\
118\end{array}$ & - & - & - & 3.72 & 1.8 & - & - & - & - & [49] \\
\hline 2012 & China, pregnant women, $N=141$ & - & - & - & 4.31 & 3.95 & - & - & - & - & [50] \\
\hline 2015 & Czech,adult population, $N=300$ & - & - & - & 2.43 & 0.76 & - & - & - & - & [51] \\
\hline 2015 & Belgium, children, $N=240$ & - & - & - & - & - & 1.8 & - & - & - & [15] \\
\hline 2006 & Thailand, famers, $N=136$ & - & - & - & - & - & $<\mathrm{LOQ}$ & 1.2 & - & - & [37] \\
\hline $\begin{array}{l}2012- \\
2016\end{array}$ & $\begin{array}{l}\text { Jerusalem, Pregnant women, } N= \\
273\end{array}$ & - & - & - & - & - & 2.72 & 0.55 & - & - & [38] \\
\hline 2011 & Belgium, population, $N=131$ & - & - & - & - & - & - & - & 2.46 & 2.24 & [17] \\
\hline 2009 & Korea, adult population, $N=1870$ & - & - & - & - & - & - & - & 2.07 & 1.53 & [40] \\
\hline $\begin{array}{l}2010- \\
2011\end{array}$ & $\begin{array}{l}\text { Murcia (Spain),Young men, } N= \\
215^{*}\end{array}$ & - & - & - & - & - & - & - & 2.3 & - & [41] \\
\hline 2012 & Tunisia, women, $N=34$ & - & - & - & - & - & - & - & 0.35 & - & [32] \\
\hline 2011 & Danish, mother, $N=145$ & - & - & - & - & - & - & - & 2.1 & 0.64 & [30] \\
\hline 2019 & $\begin{array}{l}\text { Kinshasa (DRC), population, } \\
N=15\end{array}$ & 445.39 & 0.47 & 31.35 & 0.5 & 0.482 & 0.87 & $<\mathrm{LOQ}$ & 1.36 & 40.13 & $\begin{array}{l}\text { Current } \\
\text { study }\end{array}$ \\
\hline
\end{tabular}

BPA Bisphenol A, TCS Triclosan, MeP methylparaben, EP ethylparaben, PrP n-propylparaben, $\boldsymbol{P F O S}$ perfluoro-octane sulfonic, PFOA perfluoroctanoic acid, DEP diethylphosphate, DETP diethylthiophosphate

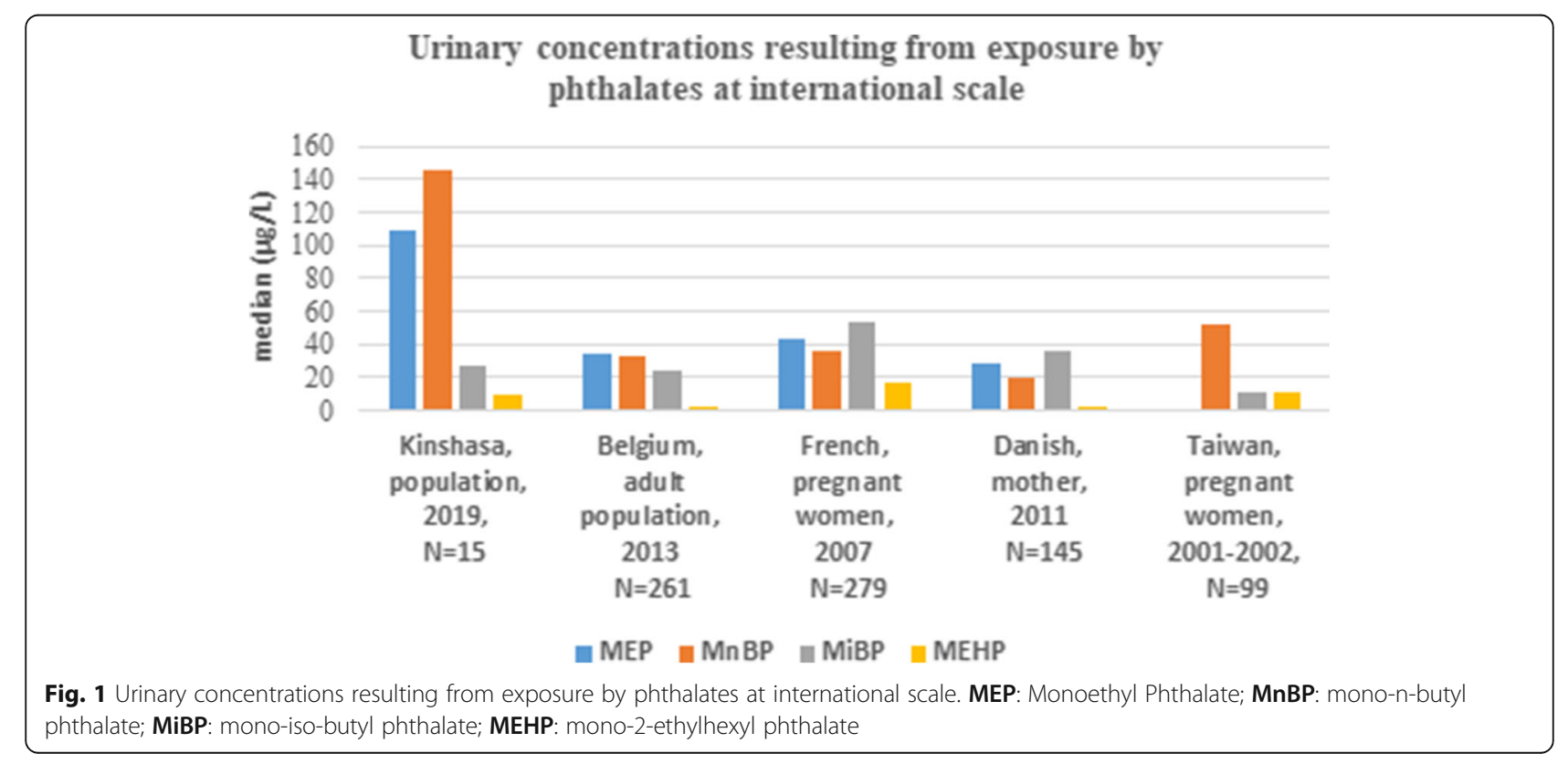




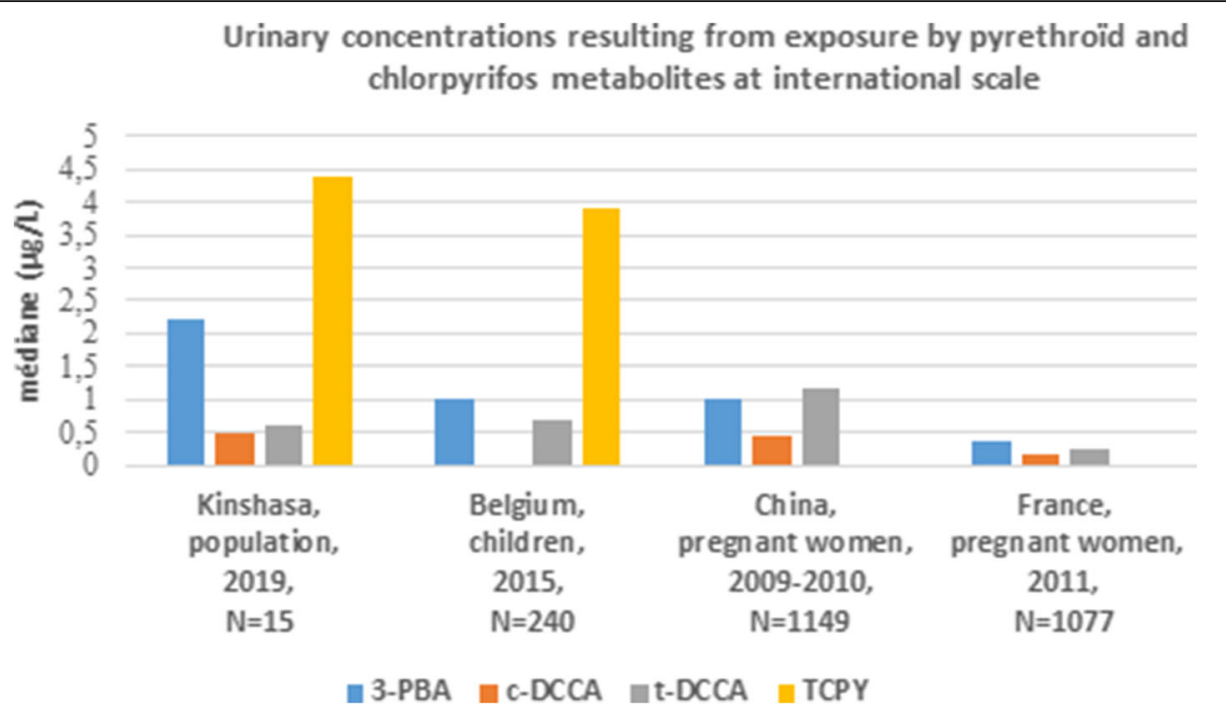

Fig. 2 Urinary concentrations resulting from exposure by pyrethroïd and chlorpyrifos metabolites at international scale. 3-PBA: 3-phenoxybenzoic acid; c-DCCA: cis-3-(2,2-dichlorovinyl)-2,2-dimethylcyclopropane-1-carboxylic acid; t-DCCA: trans-3-(2,2-dichlorovinyl)-2,2-dimethylcyclopropane-1carboxylic acid; TCPY: 3,5,6-trichloro-2-pyridinol

$86 \mu \mathrm{g} / \mathrm{L}$ on a population of 100 children recruited in 2011 in Kinshasa and aged from 1 to 5 years (Table 3). Based on a chronologic order of these publications, one can think of a possible lead exposure reduction, namely due to the sale suppression of leaded petrol throughout the country since 2009. But it is always important to maintain bio-surveillance studies as some parallel leaded petrol markets may still exist in Kinshasa. Moreover, the observed lead whole blood contents here reported could also be due to a possible release of lead into the blood from internal storage, indeed it is an element known to be accumulated in bones, soft tissues, and blood.

\section{Phthalates}

For more than half a century, phthalates have been present in a wide range of daily products, so they are used as plasticizer, especially in polyvinyl chloride (PVC) and in cosmetics [20]. In the current study, median contents in MnBP and MEP, respectively $145.19 \mu \mathrm{g} / \mathrm{L}$ and $108.56 \mu \mathrm{g} / \mathrm{L}$, were higher than those measured in 261 Belgian adults $(33.3 \mu \mathrm{g} / \mathrm{L}$ of $\mathrm{MnBP}$ and $34.3 \mu \mathrm{g} / \mathrm{L}$ of MEP) [20], than those determined in 279 French pregnant women $(35.7 \mu \mathrm{g} / \mathrm{L}$ of MnBP and $43.5 \mu \mathrm{g} / \mathrm{L}$ of MEP) [29], in 145 Danish women $(20 \mu \mathrm{g} / \mathrm{L}$ of $\mathrm{MnBP}$ and $29 \mu \mathrm{g} / \mathrm{L}$ of MEP) [30], and in 99 Taiwanese women $(52.39 \mu \mathrm{g} / \mathrm{L}$ of MnBP) [31]. This observation could probably be due to a strong presence of phthalates in plastic packaging used in Kinshasa, increasing the need for further investigations on the exposure source and the identification of susceptible population. A slightly lower median concentration in MiBP was observed when compared to the French and Danish studies as well as the median content in MEHP was slightly lower than those reported in the French and Taiwanese studies (Fig.1).

\section{Parabens}

With bactericidal and fungicidal properties, parabens are largely used in cosmetics, food, and pharmaceuticals as preservatives. Detected in all investigated samples, median concentrations of $\mathrm{MeP}(445.39 \mu \mathrm{g} / \mathrm{L})$ and $\operatorname{PrP}$ $(31.35 \mu \mathrm{g} / \mathrm{L})$ were clearly higher than those reported in 34 Tunisian women $(34.94 \mu \mathrm{g} / \mathrm{L}$ of MeP and $3.06 \mu \mathrm{g} / \mathrm{L}$ of $\mathrm{PrP})$ [32], 215 young Spanish $(17 \mu \mathrm{g} / \mathrm{L}$ of $\mathrm{MeP}$ and $0.7 \mu \mathrm{g} / \mathrm{L}$ of $\operatorname{PrP})$ [33], 145 Danish women $(14 \mu \mathrm{g} / \mathrm{L}$ of $\mathrm{MeP}$ and $1.7 \mu \mathrm{g} / \mathrm{L}$ of $\mathrm{PrP}$ ) [30], and 261 Belgian adults $(16.1 \mu \mathrm{g} / \mathrm{L}$ of $\mathrm{MeP}$ and $1.2 \mu \mathrm{g} / \mathrm{L}$ of $\operatorname{PrP})$ [20], probably due to a greater use of these preservatives in cosmetics, food and pharmaceutical products marketed in Kinshasa. Thereby, further investigations are needed to detect products containing parabens, their corresponding quantities and identify the vulnerable population. In contrast, this study has found a lower median concentration in EP $(0.47 \mu \mathrm{g} / \mathrm{L})$ (Table 4$)$.

\section{Benzophenone-3 (BP3)}

Added in cosmetics and food packaging, benzophenones have ultraviolet filters properties, reducing their deleterious effects on the skin or food. Detected in all investigated samples, the current study has found a median concentration in BP3 $(5 \mu \mathrm{g} / \mathrm{L})$ higher than those reported in the Belgian adult population $(1.3 \mu \mathrm{g} / \mathrm{L})$ [20], in Tunisian women $(1.73 \mu \mathrm{g} / \mathrm{L})$ [32], and in Danish women $(3.7 \mu \mathrm{g} / \mathrm{L})$ [30], probably due to the presence of this UV filter in cosmetics or on food packaging, reinforcing the 
need to identify the source, used concentrations, and the vulnerable population (Table 3 ).

\section{Pyrethroids and dialkylphosphate pesticides}

Pyrethroids and dialkyl-phosphates (DAPs) are among pesticides largely used in crop culture for the protection of harvests and in public health for the fight against diseases vectors. Associated with weak enzyme baggage, the immaturity in the development of some organs makes children around the world among vulnerable populations to environmental pollution [34].

In the current study, median contents in TCPY $(4.4 \mu \mathrm{g} / \mathrm{L})$, in 3 -PBA $(2.23 \mu \mathrm{g} / \mathrm{L})$, and in c-DCCA $(0.47 \mu \mathrm{g} / \mathrm{L})$ were higher than those measured in 240 Belgian children (with $1 \mu \mathrm{g} / \mathrm{L}$ of $3-\mathrm{PBA}$ and $3.9 \mu \mathrm{g} / \mathrm{L}$ of TCPY) [15], in 1149 Chinese pregnant women (with $1.01 \mu \mathrm{g} / \mathrm{L}$ of 3-PBA and $0.44 \mu \mathrm{g} / \mathrm{L}$ of c-DCCA) [35], and in 1077 French pregnant women (with $0.36 \mu \mathrm{g} / \mathrm{L}$ of 3PBA and $0.16 \mu \mathrm{g} / \mathrm{L}$ of c-DCCA) [36]. Only the median concentration in t-DCCA was lower than those on the two first studies. The high concentration observed in the present study was probably due to a very high use of pyrethroid insecticides in mosquito nets, insecticide sprays and other products for agricultural use (Fig.2). With a detection frequency of $53 \%$ for DEP and $47 \%$ for DETP with respective median contents values of $0.87 \mu \mathrm{g} / \mathrm{L}$ and $<0.5 \mu \mathrm{g} / \mathrm{L}$, this study has presented a slightly lower DAPs exposure when compared to studies on 240 Belgian children (with $1.8 \mu \mathrm{g} / \mathrm{L}$ of DEP) [15], on 136 Thai farmers (with DEP median value $<$ LOQ and $1.2 \mu \mathrm{g} / \mathrm{L}$ of DETP) [37], and on 273 pregnant women in Jerusalem (with $2.72 \mu \mathrm{g} / \mathrm{L}$ of DEP and $0.55 \mu \mathrm{g} / \mathrm{L}$ of DETP) [38] (Table 4).

\section{Bisphenols and triclosan}

Used as epoxy resin monomers, bisphenols are aromatic organic compounds used in the manufacture of plastics and poly epoxides. Added in toothpastes and cosmetics for its antibacterial properties, triclosan is likewise suspected to be endocrine disruptor for instance, it is suspected to be associated with the decrease of some biomarkers of thyroid function [39].

The median content in triclosan here observed $(40.13 \mu \mathrm{g} / \mathrm{L})$ was one or two orders of magnitude higher than those observed in a Belgian population with 131 participants $(2.24 \mu \mathrm{g} / \mathrm{L})$ [17], in 1870 Korian adults $(1.53 \mu \mathrm{g} / \mathrm{L})$ [40], and on 145 Danish women $(0.64 \mu \mathrm{g} / \mathrm{L})$ [30]. Conversely, the investigated population of Kinshasa presented a median concentration in bisphenol A $(1.36 \mu \mathrm{g} / \mathrm{L})$ lower than those reported in the above studies and that on 215 young Spanish of Murcia $(2.3 \mu \mathrm{g} / \mathrm{L})$ [41], but higher than that on 34 Tunisian women $(0.35 \mu \mathrm{g} / \mathrm{L})$ [32] (Table 4). The current study showed that the population of Kinshasa was also exposed to the new bisphenols, especially to bisphenol $\mathrm{F}$ (detected in $67 \%$ of the samples) and bisphenol S (detected in $80 \%$ of the samples) (Table 1). The exposure in the population of Kinshasa to these pollutants is probably due to the presence of triclosan in cosmetic products, toothpastes and that of bisphenols in cans and plastics sold in the city.

\section{Chlorinated pesticides}

Previously used in the fight against pests in agriculture, the p,p'-dichlorodiphenyltrichloroethane (DDT) is still used in many tropical and subtropical regions to fight against mosquitoes vector of malaria [42]. In DRC, the use of organochlorine compounds has been banned since March 2005 but Nuapia Y. et al. 2016 [43] found these compounds in raw foods (beans, cabbage, fish and beef) sold in Kinshasa.

Main metabolite of DDT in the environment and in the living organism, p,p'- dichlorodiphenyldichlorethylene (p,p'-DDE) is considered as a marker of previous exposure [44]. Detected in $87 \%$ of the samples with a median content value of $1.46 \mu \mathrm{g} / \mathrm{L}$, the investigated population in Kinshasa presented a concentration largely higher than those on 124 Belgian women (median = $0.41 \mu \mathrm{g} / \mathrm{L}$ ) [1] and on Lebanese population with 314 participants (median $=0.13 \mu \mathrm{g} / \mathrm{L}$ ) [45], probably either due to a remobilization of DDT accumulated in the soil, a late ban of DDT in DRC compared to other countries or the existence of an illegal DDT market in Kinshasa. Studies on 733 South African pregnant women and on 24. Bolivian women farmers reported a higher median concentration $[42,46]$ (Table 3).

\section{Polychlorinated biphenyls}

Used as insulating fluid in electrical equipment and additives in putty, polychlorinated biphenyls (PCB) are POPs as they also remain intact in the environment for many years. Comparing median contents in PCB 153 of studies performed on 251 Belgians $(0.36 \mu \mathrm{g} / \mathrm{L})$ [1], 314 Lebanese $(0.12 \mu \mathrm{g} / \mathrm{L})$ [45], and on 353 Afro-Americans $(1.42 \mu \mathrm{g} / \mathrm{L})$ [47], the investigated population in Kinshasa was weakly exposed to these compounds (median concentration in the present study $=0.081 \mu \mathrm{g} / \mathrm{L}$ ), probably due to their low use in the Kinshasan market (Table 3).

\section{Perfluoroalkyl substances}

Surfactants with high thermal stability, perfluoroalkyl substances (PFAS) are found in various everyday products (kitchen utensils, stoves, microwave packaging, raincoats, sportswear, etc.) thanks to their waterproofing and non-stick properties [8].

In the current study, a low contamination in PFAS (for instance, median PFOS $=0.5 \mathrm{ng} / \mathrm{mL}$ and median PFOA = $0.48 \mathrm{ng} / \mathrm{mL}$ ) was observed in the population 
comparatively to studies on 237 Belgians (with median concentration of $3.61 \mu \mathrm{g} / \mathrm{L}$ for PFOS and $1.6 \mu \mathrm{g} / \mathrm{L}$ for PFOA) [48], 118 American teenagers (median PFOS = $3.72 \mathrm{ng} / \mathrm{mL}$ and median PFOA $=1.8 \mathrm{ng} / \mathrm{mL}$ ) [49], 141 Chinese pregnant women (median PFOS $=4.31 \mathrm{ng} / \mathrm{mL}$ and median PFOA $=3.95 \mathrm{ng} / \mathrm{mL}$ ) [50], and on 300 Czech adults (median PFOS $=2.43 \mathrm{ng} / \mathrm{mL}$ and median PFOA $=$ $0.76 \mathrm{ng} / \mathrm{mL}$ ) [51], reflecting a probable low presence of these compounds in the market of Kinshasa (Table 4).

\section{Phenolic organohalogens}

Contamination by phenolic organohalogens (POH) seemed to be weak in the investigated population: pentachlorophenol, a pesticide used namely in the protection of timber, was only detected in $14 \%$ of the population, while it was present in $100 \%$ of 272 Belgian volunteers as reported by Dufour et al. 2017 [52], with a median content value of $593 \mathrm{pg} / \mathrm{mL}$ (both populations were explored with the same analytical method). Likewise, weak was the contamination by $\mathrm{OH}-\mathrm{CBs}$, metabolites of PCBs. Only 4-OH-CB 187 was found in more than $50 \%$ of individuals (57\%), with a median concentration of $2.4 \mathrm{pg} / \mathrm{mL}$ while Dufour et al. 2017 [52] highlighted a detection frequency of $100 \%$ and a median level of $39.4 \mathrm{pg} / \mathrm{mL}$ in the Belgian population, reflecting a reduced contamination observed for $\mathrm{PCBs}$ in the investigated population of Kinshasa.

\section{Brominated flame retardants}

Finally, brominated flame retardants (BFR) are compounds incorporated in many materials (especially plastics) to increase their fire resistance and to help reducing the risk of fire. They are therefore found in many everyday products, including vehicles, clothes, furniture, electronic equipment, etc. The investigated population of Kinshasa seemed to escape to these compounds as the most frequent substances, PBDE 47 and 153 were only detected in $27 \%$ of the samples, with maximum concentrations of 15 and $13 \mathrm{pg} / \mathrm{mL}$, respectively. This situation is close to that observed in Belgium, with detection frequencies lower than $40 \%$ for all PBDEs highlighted with the same analytical method [48], but largely far from the contamination observed in the USA, where diverse studies showed median levels in total PBDEs ranging from 10 to values higher than $40 \mathrm{ng} / \mathrm{g}$ in lipids or approximatively $73.5 \mathrm{pg} / \mathrm{mL}$ and $294 \mathrm{pg} / \mathrm{mL}$ [53].

\section{Future large scale studies}

This pilot study brings us several lessons. First, it is difficult to collect blood samples in the population of Kinshasa. Indeed, because of spiritual considerations or superstition, many people we asked to participate to the study refuse to give blood sample. This element should be considered when writing the final protocol for larger scale study: blood sample collection will be associated with important difficulties, waste of time and could biased the participant recruitment by potentially excluding some socio-economic profiles from the population. Secondly, the profile of pollutant contamination observed in the Kinshasa's population is highly different from those highlighted in Western countries as like Belgium.

Considering these two parameters, pollutants families could be classified by order of priority. In the group of "high priority" pollutants, we included As, triclosan and parabens, these pollutants were measured in urine at levels more than 10-fold higher than those observed in other general populations. Considering the high exposition levels observed for these compounds, they should be included in future investigations. Phthalates and BP3 are quantified with the same analytical method than parabens and BPs are measured simultaneously to triclosan. Consequently, these pollutants could be added to the high priority group without additional costs. The second group, "intermediate priority" pollutants groups gathers glyphosate, pyrethroids and dialkylphosphate pesticides that were measured at levels similar to those observed in other populations. Lead and OCPs were also added to the "intermediate priority" group, the contamination determined in our population for these pollutants was relatively high but they are measured in blood and are thus more difficult to investigate. The pollutants of this second group will be included or not in further studies according to the available resources. In the last group: "low priority" pollutants, we included PFASs, POHs, PCBs and BFRs, these compounds were measured in low concentrations in our population compared to Western countries and require blood samples, thus they probably will not be included in large scale study in Kinshasa.

The recruitment is also an important parameter to consider during the redaction of the protocol. In order to avoid spiritual considerations, religion communities and opinion leaders should be involved in the recruitment process, this should allow an optimal sensitization and recruitment of study population. Concerning the study cohort composition, we consider two options. First, we could design our study protocol to explore the whole general population. The recruitment will be targeted in order to recruit a similar number of individuals for each age group (18-29 years, 30-39 years, 40-49 years, 50-59 years, $>60$ years) and gender group, children could also be included in the protocol (age classes: $<6$ years, $6-12$ years, $12-18$ years). The second option is to focus the recruitment on vulnerable individuals i.e. children, adolescents, and women of childbearing age. Indeed, the childhood and the puberty are associated 
with important developmental changes and environmental pollutants could interfere with this physiological process, especially endocrine disruptors. In the same way, contamination during in utero life could be associated with important long-term consequences, therefore the exploration of women of childbearing age is of primary importance [2].

\section{Conclusion}

In conclusion, thanks to the information collected during this preliminary study, 3 protocols could be considered:

The "minimal" protocol: for each age group (18-29 years, $30-39$ years, $40-49$ years, $50-59$ years and $>60$ years), 5 women and 5 men will be randomly (notwithstanding the profession) selected. To recruit volunteers, announcement will be made on the local radio and during the religious services at the church. Each volunteer will be asked to provide urine sample and to complete questionnaire concerning his demographics and life habits. In urine samples, we will measure the concentrations of As, triclosan, bisphenols, phthalates and parabens.

The "intermediate" protocol: recruitment will be the same as in "minimal" protocol but in addition, we will determinate in urine samples the concentrations of glyphosate, pyrethroids and dialkylphosphate pesticides. We will also ask to the volunteers to provide blood samples in order to estimate the contamination by lead and OCP. Blood samples collection is difficult, some effort will be necessary and contacts will have to be established with community and religious leaders to try to overcome spiritual and superstitious fears.

The "optimal" protocol: modalities of the "intermediate" protocol (by excluding the collection of blood samples) will be extended to children. Ten girls and 10 boys will be randomly selected by age group (< 6 years, $6-12$ years, $12-18$ years). In additions, 30 women in childbearing age (18-29 years) will be recruited (for urinary and blood exploration).

The protocol chosen for the larger scale study will depend on the resources collected to perform these investigations, number of individuals recruited in each age group could be adjusted if resource are sufficient. The present report clearly indicates that the population of Kinshasa is not spared by the investigated environmental pollutants. Therefore, it is of paramount importance to scale-up and validate this study to a larger population of Kinshasa to obtain a database on pollutants and identify potential hot spots of exposure, in order to establish relationship between certain socio-demographic characteristics (age, sex, food, smoking, professional activity, etc.) and the level of exposure to pollutants, to investigate possible sources of exposure and to explore potential associations between the contamination and the prevalence of some chronic diseases in the population of Kinshasa.

\section{Abbreviations}

DRC : Democratic Republic of Congo; POPs: Persistent organic pollutants; OCP: Organochlorine pesticides; PCB: Polychlorinated biphenyls;

BFR: Brominated flame retardants; $\mathrm{POH}$ : Phenolic organo-halogens;

PFAS: Perfluoroalkyl substances; FMOC : Fluorenylmethoxycarbonyl chloride;

c- and t-DCCA : cis- and trans-3-(2,2-dichlorovinyl)-2.2-dimethylcyclopropane carboxylic acid; 3-PBA: 3-phenoxybenzoic acid; 4F-3-PBA: 4-fluoro-3-

phenoxybenzoic acid; DBCA : 3-(2,2-dibromovinyl)-2.2-dimethylcyclopropane carboxylic acid; TCPY: 3,5,6-trichloro-2-pyridinol; MTBSTFA: N-tert-

butyldimethylsilyl-N-methyltrifluoroacetamide; DAPs : Dialkylphosphates; DMTP : Dimethylthiophosphate; DMDTP : Dimethyldithiophosphate; DEP

: Diethylphosphate; DETP : Diethylthiophosphate; DEDTP

: Diethyldithiophosphate; SPE : Solid phase extraction; MEP : Monoethyl phthalate; MiBP : Mono-iso-butyl phthalate; MnBP : Mono-n-butyl phthalate; MBzP : Monobenzyl phthalate; MEHP : Mono-2-ethylhexyl phthalate; $5-\mathrm{OH}-$ MEHP : Mono-2-ethyl-5-hydroxyhexyl phthalate; 5-oxo-MEHP : Mono-2-ethyl5-oxohexyl phthalate; MeP : Methylparaben; EP : Ethylparaben; PrP : npropylparaben; BP : n-butylparaben; BP-3 : Benzophenone-3; TCS : Triclosan; BP : Bisphenols; HCB : Hexachlorobenzene4;4'-DDE4,4'-dichlorodiphenyldichloroethylene; PBDEs: Polybrominated diphenylethers; PFOS: Perfluorooctane sulfonic; PFOA: Perfluoroctanoic acid; PFHxS: Perfluorohexane sulfonate; PFNA: Perfluorononanoic acid; PFDA: Perfluorodecanoic acid; PFHpA: Perfluoroheptanoic acid; PFUdA: Perfluoroundecanoic acid; PCP: Pentachlorophenol; TBBPA: Tetrabromobisphenol A; 2,4,6-TBP: 2,4,6tribromophenol; 2,3,6-TBP: 2,3,6-tribromophenol; 2,4,5-TBP: 2,4,5tribromophenol2,3,4,6-TeBP2,3,4,6-tetrabromophenol; 6-OH-BDE 47: 6hydroxy-polybromodiphenylether 47; 5-OH-BDE 47: 5-hydroxypolybromodiphenylether 47; 5'-OH-BDE 99: 5'-hydroxypolybromodiphenylether 99; 4-OH-CB 107: 4-hydroxy-polychlorinated biphenyl 107; 3-OH-CB 138: 3-hydroxy-polychlorinated biphenyl 138; 4-OHCB 146: 4-hydroxy-polychlorinated biphenyl 146; 3-OH-CB 153: 3-hydroxypolychlorinated biphenyl 153; 4-OH-CB 172: 4-hydroxy-polychlorinated biphenyl 172; 3-OH-CB 180: 3-hydroxy-polychlorinated biphenyl 180; 4-OHCB 187: 4-hydroxy-polychlorinated biphenyl 187; LOQ: Limit of Quantification; DF: Detection Frequency; IARC: International Agency for Research on Cancer

\section{Supplementary Information}

The online version contains supplementary material available at https://doi. org/10.1186/s13690-021-00717-x.

Additional file 1. : Supplementary materials.

\section{Acknowledgments}

At the end of this pilot study, may the "ARES-CCD" (Académie de Recherche et d'Enseignement Supérieur-Commission de la Coopération au Développement) finds here the expression of our deep gratitude for the support provided to TB and all study participants for their commitment to this investigation.

\section{Authors' contributions}

TB and PD drafted the manuscript. CP, JN, JPM, JM, RM, and CC read, commented the draft versions, and approved the final manuscript. All the authors read and approved the final manuscript

\section{Funding}

ARES-CCD (Académie de Recherche et d'Enseignement SupérieurCommission de la Coopération au Développement) was the funding agent of this study.

\section{Availability of data and materials}

The datasets used and/or analysed during the current study are available from the corresponding author on a reasonable request. 


\section{Declarations}

\section{Ethics approval and consent to participate}

Ethics approval was obtained from the national health ethics committee in the Democratic Republic of Congo. Firstly, participants were informed about the study interest and then, written informed consent was obtained from each participant during data collection. Participants were free to refuse to take part in the study as well as to withdraw any time along the study. Study results were strictly confident according to the declaration of Helsinki.

\section{Consent for publication}

Not applicable.

\section{Competing interests}

The authors declare that there is no competing interest regarding the publication of this paper.

\section{Author details \\ ${ }^{1}$ Faculty of Pharmaceutical Sciences, University of Kinshasa, Kinshasa, Democratic Republic of the Congo. ${ }^{2}$ Laboratory of Clinical, Forensic and Environmental Toxicology, University of Liege (ULiege), CHU (B35), 4000 Liege, Belgium. ${ }^{3}$ Center for Interdisciplinary Research on Medicines (C.I.R.M), University of Liege (ULiege), CHU (B35), 4000 Liege, Belgium.}

Received: 11 March 2021 Accepted: 26 October 2021 Published online: 15 November 2021

\section{References}

1. Pirard C, Compere S, Firquet $\mathrm{K}$, Charlier C. The current environmental levels of endocrine disruptors (mercury, cadmium, organochlorine pesticides and $\mathrm{PCBs}$ ) in a Belgian adult population and their predictors of exposure. Int J Hygiene Environ Health. 2018;221(2):211-22. https://doi.org/10.1016/j.ijheh.2 017.10.010.

2. UNEP/WHO. State of the science of endocrine disrupting chemicals. Geneva, Switzerland: United Nations Environment Programme/World Health Organization; 2012.

3. Cohn BA, Cirillo PM, Christianson RE. Prenatal DDT exposure and testicular cancer: a nested case control study. Arch Environ Occup Health. 2010;65(3): 127-34. https://doi.org/10.1080/19338241003730887.

4. Wagner-Schuman M, Richardson JR, Auinger P, Braun JM, Lanphear BP, Epstein $\mathrm{JN}$, et al. Association of pyrethroid pesticide exposure with attention-deficit/hyperactivity disorder in a nationally representative sample of U.S. children. Environ Health. 2015;14:44. https://doi.org/10.1186/s12940015-0030-y.

5. Sabatier P, Poulenard J, Fanget B, Reyss J-L, Develle A-L, Wilhelm B, et al Long-term relationships among pesticide applications, mobility, and soil erosion in a vineyard watershed. Proc Natl Acad Sci USA. 2014;111(44): 15647-52. https://doi.org/10.1073/pnas.1411512111.

6. Marotta V, Russo G, Gambardella C, Grasso M, La Sala D, Chiofalo MG, et al. Human exposure to bisphenol AF and diethylhexylphthalate increases susceptibility to develop differentiated thyroid cancer in patients with thyroid nodules. Chemosphere. 2019;218:885-94. https://doi.org/10.1016/j. chemosphere.2018.11.084.

7. Pirard C, Koppen G, De Cremer K, Van Overmeire I, Govarts E, Dewolf M-C, et al. Hair mercury and urinary cadmium levels in Belgian children and their mothers within the framework of the COPHES/DEMOCOPHES projects. Sci Total Environ. 2014;472:730-40. https://doi.org/10.1016/j.scitotenv.2013.11.02 8.

8. Dufour P, Pirard C, Seghaye M-C, Charlier C. Association between organohalogenated pollutants in cord blood and thyroid function in newborns and mothers from Belgian population. Environ Pollut. 2018;238: 389-96. https://doi.org/10.1016/j.envpol.2018.03.058.

9. Åkesson A, Lundh T, Vahter M, Bjellerup P, Lidfeldt J, Nerbrand C, et al. Tubular and glomerular kidney effects in Swedish women with low environmental cadmium exposure. Environ Health Perspect. 2005;113(11): 1627-31. https://doi.org/10.1289/ehp.8033.

10. Duan $Y$, Yao $Y$, Wang B, Han L, Wang L, Sun $H$, et al. Association of urinary concentrations of bisphenols with type 2 diabetes mellitus: A case-control study. Environ Pollut. 2018;243:1719-26. https://doi.org/10.1016/j.envpol.201 8.09.093.
11. Punga-Maole AM-L, Moningo DM, Kayembe PK, Tshikuela ML, Kabongo JMM. Étude de dépistage du cancer de la prostate au sein d'une population d'employés d'une entreprise de Kinshasa en république démocratique du Congo: Taux de détection et facteurs de risques nutritionnels et géographiques. Progrès en Urologie. 2008;18:512-8. https://doi.org/10.1016/ j.purol.2008.04.009.

12. Mashinda KD, Kayembe KP, Mapatano MA. Prévalence du cancer en République Démocratique du Congo: données anatomopathologiques recueillies aux Cliniques Universitaires et à l'Hôpital Général de Référence de Kinshasa. Annales africaines de médecine. 2012;5:1087-93.

13. Tshimpi A, Ndarabu T, Batumona B, Tambwe F, JMN K. Cancer in Democratic Republic of Congo on 2016. Annales africaines de médecine:2016;9:2331-2.

14. Tuakuila J, Kabamba M, Mata H, Mbuyi F. Tentative reference values for environmental pollutants in blood or urine from the children of Kinshasa. Chemosphere. 2015;139:326-33. https://doi.org/10.1016/j.chemosphere.2015. 06.039.

15. Pirard C, Remy S, Giusti A, Champon L, Charlier C. Assessment of children's exposure to currently used pesticides in Wallonia. Belgium Toxicol Lett. 2020:329:1-11. https://doi.org/10.1016/j.toxlet.2020.04.020.

16. Dewalque L, Pirard C, Dubois N, Charlier C. Simultaneous determination of some phthalate metabolites, parabens and benzophenone-3 in urine by ultra high pressure liquid chromatography tandem mass spectrometry. J Chromatogr B. 2014;949-950:37-47. https://doi.org/10.1016/j.jchromb.2014. 01.002 .

17. Pirard C, Sagot C, Deville M, Dubois N, Charlier C. Urinary levels of bisphenol a, triclosan and 4-nonylphenol in a general Belgian population. Environ Int. 2012;48:78-83. https://doi.org/10.1016/j.envint.2012.07.003.

18. Pirard C, Charlier C. Simple and fast method for the measurement of legacy and novel brominated flame retardants in human serum. Chemosphere. 2018;211:918-25. https://doi.org/10.1016/j.chemosphere.2018.08.012.

19. Dufour P, Pirard C, Charlier C. Validation of a novel and rapid method for the simultaneous determination of some phenolic organohalogens in human serum by GC-MS. J Chromatogr B. 2016;1036-1037:66-75. https:// doi.org/10.1016/j.jchromb.2016.10.002.

20. Dewalque L, Pirard C, Charlier C. Measurement of urinary biomarkers of parabens, Benzophenone-3, and phthalates in a Belgian population. Biomed Res Int. 2014;2014:1-13. https://doi.org/10.1155/2014/649314.

21. Schulz C, Butte W. Revised reference value for pentachlorophenol in morning urine. Int J Hygiene Environ Health. 2007;210(6):741-4. https://doi. org/10.1016/j.ijheh.2006.11.004.

22. Molina-Villalba I, Lacasaña M, Rodríguez-Barranco M, Hernández AF, Gonzalez-Alzaga B, Aguilar-Garduño C, et al. Biomonitoring of arsenic, cadmium, lead, manganese and mercury in urine and hair of children living near mining and industrial areas. Chemosphere. 2015;124:83-91. https://doi. org/10.1016/j.chemosphere.2014.11.016.

23. Musa Obadia P, Kayembe-Kitenge T, Haufroid V. Banza Lubaba Nkulu C, Nemery B. preeclampsia and blood lead (and other metals) in Lubumbashi, DR Congo. Environ Res. 2018;167:468-71. https://doi.org/10.1016/j.envres.2 018.07.032.

24. Fierens S, Rebolledo J, Versporten A, Brits E, Haufroid V, De Plaen P, et al. Human biomonitoring of heavy metals in the vicinity of non-ferrous metal plants in Ath. Belgium Arch Public Health. 2016;74(1):42. https://doi.org/1 0.1186/s13690-016-0154-8

25. Connolly A, Leahy M, Jones K, Kenny L, Coggins MA. Glyphosate in Irish adults - A pilot study in 2017. Environ Res. 2018;165:235-6. https://doi.org/1 0.1016/j.envres.2018.04.025

26. Conrad A, Schröter-Kermani C, Hoppe H-W, Rüther M, Pieper S, KolossaGehring M. Glyphosate in German adults - Time trend (2001 To 2015) of human exposure to a widely used herbicide. Int J Hygiene Environ Health. 2017;220(1):8-16. https://doi.org/10.1016/j.jiheh.2016.09.016.

27. Li A, Zhuang T, Shi J, Liang Y, Song M. Heavy metals in maternal and cord blood in Beijing and their efficiency of placental transfer. J Environ Sci (China). 2019;80:99-106. https://doi.org/10.1016/j.jes.2018.11.004.

28. Tuakuila J, Kabamba M, Mata H, Mata G. Blood lead levels in children after phase-out of leaded gasoline in Kinshasa, the capital of Democratic Republic of Congo (DRC). Arch Public Health. 2013;71(1):5. https://doi.org/1 0.1186/0778-7367-71-5

29. Zeman FA, Boudet C, Tack K, Floch Barneaud A, Brochot C, Péry ARR, et al, Exposure assessment of phthalates in French pregnant women: Results of the ELFE pilot study. Int J Hygiene Environ Health. 2013;216(3):271-9. https://doi.org/10.1016/j.jiheh.2012.12.005. 
30. Frederiksen H, Nielsen JKS, Mørck TA, Hansen PW, Jensen JF, Nielsen O, et al. Urinary excretion of phthalate metabolites, phenols and parabens in rural and urban Danish mother-child pairs. Int J Hygiene Environ Health. 2013;216(6):772-83. https://doi.org/10.1016/j.ijheh.2013.02.006

31. Lin S, Ku H-Y, Su P-H, Chen J-W, Huang P-C, Angerer J, et al. Phthalate exposure in pregnant women and their children in central Taiwan. Chemosphere. 2011;82(7):947-55. https://doi.org/10.1016/j.chemosphere.201 0.10 .073 .

32. Jiménez-Díaz I, Artacho-Cordón F, Vela-Soria F, Belhassen H, Arrebola JP, Fernández MF, et al. Urinary levels of bisphenol A, benzophenones and parabens in Tunisian women: A pilot study. Sci Total Environ. 2016;562:81-8. https://doi.org/10.1016/j.scitotenv.2016.03.203.

33. Adoamnei E, Mendiola J, Moñino-García M, Vela-Soria F, Iribarne-Durán LM Fernández MF, et al. Urinary concentrations of parabens and reproductive parameters in young men. Sci Total Environ. 2018;621:201-9. https://doi. org/10.1016/j.scitotenv.2017.11.256.

34. Wu C, Feng C, Oi X, Wang G, Zheng M, Chang X, et al. Urinary metabolite levels of pyrethroid insecticides in infants living in an agricultural area of the province of Jiangsu in China. Chemosphere Mars. 2013;90(11):2705-13. https://doi.org/10.1016/j.chemosphere.2012.11.050.

35. Qi X, Zheng M, Wu C, Wang G, Feng C, Zhou Z. Urinary pyrethroid metabolites among pregnant women in an agricultural area of the Province of Jiangsu, China. Int J Hygiene Environ Health. 2012;215(5):487-95. https:// doi.org/10.1016/j.jijheh.2011.12.003.

36. Dereumeaux C, Saoudi A, Goria S, Wagner V, De Crouy-Chanel P, Pecheux $M$, et al. Urinary levels of pyrethroid pesticides and determinants in pregnant French women from the Elfe cohort. Environ Int. 2018;119:89-99. https://doi.org/10.1016/j.envint.2018.04.042.

37. Panuwet $P$, Prapamontol T, Chantara S, Thavornyuthikarn P, Montesano MA, Whitehead RD, et al. Concentrations of urinary pesticide metabolites in small-scale farmers in Chiang Mai Province, Thailand. Sci Total Environ. 2008; 407(1):655-68. https://doi.org/10.1016/j.scitotenv.2008.08.044.

38. Ein-Mor E, Ergaz-Shaltiel Z, Berman T, Göen T, Natsheh J, Ben-Chetrit A, et al. Decreasing urinary organophosphate pesticide metabolites among pregnant women and their offspring in Jerusalem: Impact of regulatory restrictions on agricultural organophosphate pesticides use? Int J Hygiene Environ Health. 2018;221(5):775-81. https://doi.org/10.1016/j.jiheh.2018.03. 013.

39. Skarha J, Mínguez-Alarcón L, Williams PL, Korevaar TIM, de Poortere RA, Broeren MAC, et al. Cross-sectional associations between urinary triclosan and serum thyroid function biomarker concentrations in women. Environ Int. 2019;122:256-62. https://doi.org/10.1016/j.envint.2018.11.015.

40. Kim K, Park H, Yang W, Lee JH. Urinary concentrations of bisphenol A and triclosan and associations with demographic factors in the Korean population. Environ Res. 2011;111(8):1280-5. https://doi.org/10.1016/j. envres.2011.09.003

41. Adoamnei E, Mendiola J, Vela-Soria F, Fernández MF, Olea N, Jørgensen N, et al. Urinary bisphenol A concentrations are associated with reproductive parameters in young men. Environ Res. 2018;161:122-8. https://doi.org/10.1 016/j.envres.2017.11.002.

42. Mercado LA, Freille SM, Vaca-Pereira JS, Cuellar M, Flores L, Mutch E, et al. Serum concentrations of $p, p^{\prime}$-dichlorodiphenyltrichloroethane ( $\left.p, p^{\prime}-D D E\right)$ in a sample of agricultural workers from Bolivia. Chemosphere Juin. 2013; 91(10):1381-5. https://doi.org/10.1016/j.chemosphere.2012.12.023.

43. Nuapia Y, Chimuka L, Cukrowska E. Assessment of organochlorine pesticide residues in raw food samples from open markets in two African cities. Chemosphere. 2016;164:480-7. https://doi.org/10.1016/j.chemosphere.2016. 08.055.

44. Charlier C, Plomteux G. Endocrine disruption and organochlorines residues. Acta Clin Belg. 2002;57(Suppl 1):2-7.

45. Helou K, Harmouche-Karaki M, Karake S, Narbonne J-F. A review of organochlorine pesticides and polychlorinated biphenyls in Lebanon: Environmental and human contaminants. Chemosphere. 2019;231:357-68. https://doi.org/10.1016/j.chemosphere.2019.05.109.

46. Murray J, Eskenazi B, Bornman R, Gaspar FW, Crause M, Obida M, et al. Exposure to DDT and hypertensive disorders of pregnancy among south African women from an indoor residual spraying region: the VHEMBE study. Environ Res. 2018;162:49-54. https://doi.org/10.1016/j.envres.2017.12.006.

47. Pavuk M, Olson JR, Sjödin A, Wolff P, Turner WE, Shelton C, et al. Serum concentrations of polychlorinated biphenyls (PCBs) in participants of the
Anniston Community Health Survey. Sci Total Environ. 2014;473-474:286-97. https://doi.org/10.1016/j.scitotenv.2013.12.041.

48. Dufour P, Pirard C, Petrossians P, Beckers A, Charlier C. Association between mixture of persistent organic pollutants and thyroid pathologies in a Belgian population. Environ Res. 2020;181:108922. https://doi.org/10.1016/j. envres.2019.108922.

49. Gaylord A, Berger Kl, Naidu M, Attina TM, Gilbert J, Koshy TT, et al. Serum perfluoroalkyl substances and lung function in adolescents exposed to the World Trade Center disaster. Environ Res. 2019;172:266-72. https://doi.org/1 0.1016/j.envres.2019.02.024

50. Jiang W, Zhang Y, Zhu L, Deng J. Serum levels of perfluoroalkyl acids (PFAAs) with isomer analysis and their associations with medical parameters in Chinese pregnant women. Environ Int. 2014;64:40-7. https://doi.org/10.1 016/j.envint.2013.12.001.

51. Sochorová L, Hanzlíková L, Černá M, Drgáčová A, Fialová A, Švarcová A, et al. Perfluorinated alkylated substances and brominated flame retardants in serum of the Czech adult population. Int J Hygiene Environ Health. 2017; 220(2, Part A):235-43. https://doi.org/10.1016/j.jijheh.2016.09.003.

52. Dufour P, Pirard C, Charlier C. Determination of phenolic organohalogens in human serum from a Belgian population and assessment of parameters affecting the human contamination. Sci Total Environ. 2017;599-600:185666. https://doi.org/10.1016/.j.scitotenv.2017.05.157.

53. Fromme H, Becher G, Hilger B, Völkel W. Brominated flame retardants exposure and risk assessment for the general population. Int J Hyg Environ Health. 2016;219(1):1-23. https://doi.org/10.1016/j.ijheh.2015.08.004.

\section{Publisher's Note}

Springer Nature remains neutral with regard to jurisdictional claims in published maps and institutional affiliations.
Ready to submit your research? Choose BMC and benefit from:

- fast, convenient online submission

- thorough peer review by experienced researchers in your field

- rapid publication on acceptance

- support for research data, including large and complex data types

- gold Open Access which fosters wider collaboration and increased citations

- maximum visibility for your research: over $100 \mathrm{M}$ website views per year

At BMC, research is always in progress.

Learn more biomedcentral.com/submissions 